\title{
TAILA DHARA IN NIDRANASHA W.S.R. TO INSOMNIA
}

\author{
Patil Sumit Raosaheb* ${ }^{1}$, Dike Rashmi Gajanan ${ }^{2}$
}

1. Associate Prof. \& H.O.D,

2. Assistant Professor

Dept. of Panchakarma, Dr. J.J.Magdum Ayurved Medical college, Jaysingpur

*Corresponding Author: dr.sumit.ayu @ gmail.com

\section{ABSTRACT}

Ayurveda says Nidra yuktam Sukham Dukkham, In fact, it says that sleep is one of the three pillars of health. Insomnia or Nidranasha, is not just about being not getting proper sleep but it means that the nervous system has been weakened and reduces our ability to cope up with daily sleep. Insomnia is named as Nidranasha, happens due to vitiation of Kapha, Pitta and Vata dosha. Proper and deep sleep helps the person keep Energetic, Enthusiastic, does Brumhana, increases the Bala, increases vigour and vitality and most it keeps the Mind in stable state for gaining knowledge. Insomnia means inability to get sleep at night or inability to have a restful and sound sleep. Insomnia is typically followed by daytime sleepiness, low energy, irritability, and a depressed mood. Insomnia can be short term, lasting for days or weeks, or long term, lasting more than a month. Insomnia can occur independently or as a result of another problem. Conditions that can result in insomnia include psychological stress, chronic pain, heart failure, hyperthyroidism, heartburn, Alzhei mer's disease and Parkinson's disease, Arthritis, menopause, and certain medications, and drugs such as caffeine, nicotine, and alcohol.

Treatment of Insomnia:- PanchakarmaTaila dhara a type of Shirodhara is very much useful in combacting the Insomnia caused due to various above said disorders. So its a demand of time to know about the real sleep and the disturbed sleep according to Ayurveda and Mordern medicines also and effect of Taila Dhara Brahmi,Jatamamsi siddha) in treating nsomnia.

KEYWORDS:-Ayurveda, Nidranasha, Panchakarma \& Taila dhara.

\section{INTRODUCTION}

\section{Insomnia: -}

Insomnia is a type of sleep disorder. Individuals with insomnia find it difficult to fall asleep, stay asleep, or both. People with insomnia often don't feel refreshed when they wake up from sleeping, either. This can lead to fatigue and other symptoms. Insomnia is typically followed by daytime sleepiness, low energy, irritability, and a depressed mood. It may result in an increased risk of motor vehicle collisions, as well as problems focusing and learning. Insomnia can be short term, lasting for days or weeks, or long term, lasting more than a month. 
Insomnia can occur independently or as a result of another problem, Conditions that can result in insomnia include psychological stress, chronic pain, heart

failure, hyperthyroidism, heartburn, menop ause, certain medications, and drugs such as caffeine, nicotine, and alcohol. Other risk factors include working night shifts and sleep apnea. Diagnosis is based on sleep habits and an examination to look for underlying causes. A sleep study may be done to look for underlying sleep disorders. Screening may be done with two questions: "do you experience difficulty sleeping?" and "do you have difficulty falling or staying asleep. People over the age of 55 are affected more often than younger people. Females are more often affected than males.

\section{Types}

Insomnia can be classified as transient, acute, or chronic.

1. Transient insomnia lasts for less than a week. It can be caused by another disorder, by changes in the sleep environment, by the timing of sleep, severe depression, or by stress.

2. Acute insomnia is the inability to consistently sleep well for a period of less than a month. Insomnia is present when there is difficulty initiating or maintaining sleep or when the sleep that is obtained is non-refreshing or of poor quality. It's also known as short term insomnia or stress related insomnia.

3. Chronic insomnia lasts for longer than a month. It can be caused by another disorder, or it can be a primary disorder. Its effects can vary according to its causes. They might include muscular weariness, hallucinations, and/or mental fatigue. Chronic insomnia can cause double vision.

Causes of Insomnia: - Long gaps between meals, drinking of coffee or tea before going to bed. The intake of dry and cold food, Withheld emotions, Disturbed sleeping patterns, Anger, Overwork, ill health, Worrying, Over excitement, Emotional disorders such as depression, Anxiety , Stress disorder, Neurological disorders such as Alzheimer's disease and Parkinson's disease, Arthritis, Use of caffeinated beverages, Heart failure, Gastro-intestinal disorders, such as heartburn, Menopause and hot flashes.

Charaka in Sutra sthana $21^{\text {st }}$ chapter said the importance of Nidra and adverse effects of Nidranasha (Anidra). He says when person get proper sleep will be benefited with Dhatu samyata, Bala, Kapha vruddhi in turn does the Sharira Pushti.

Risk factors of Insomnia: Psychiatrist Problems, Obesity, Risk of Accident, Risk in Driving Poor Immune System, Poor Job Performance, Mental Irritability, Social Issues, Behavioral Changes, Palpitation, Phobia, Intolerance, Nervous Dysfunction.

\section{AIMS \& OBJECTIVES: -}

To study about Insomnia (Nidranasha) and it's treatment principals from Ayurvedic Samhita Granthas, Dharakalpa (Sahasrayoga) other Research Journals and web.

MATERIALS: - Charak Samhita, Sushrut Samhita, Dharakalpa of Sahasrayoga, Modern Medicine Books and website 
METHODS:- Charaka Su. $21^{\text {st }}$ chapter says, Nidra (Sleep):- When the mind and the sense organs are tiered and retract from their respective functions, then the person goes to sleep (Nidra). Effects of proper sleep on the body: It gives Sukha (happiness),Pushti (nourishment), Bala (strength), Vrishata(Vigour), Gyaan (knowledge), Jeevita (healthy life). Effects of less sleep on the body: Dukha (unhappiness), Karshyata (emaciation), Abala (weakness), Kleebata (impotant) Agyana (impaired knowledge or unwise) Destroys the life. Just like taking proper food keeps the body healthy the proper sleep leads to Arogya (health) and Sukha (happiness).

- Ayurveda recognizes the importance of sleep to health. In fact, it says that sleep, diet and Brahmacharya are the three pillars of health. Insomnia Nidranasha, is not just about being no getting sleep but it means that the nervous system has been weakened and reduces our ability to cope up and getting tired. Insomnia is called Nidranasha, an imbalance in Tarpaka Kapha, Sadhaka

Pitta and PranaVayu, but the ultimate goal of an Ayurvedic approach to Nidranasha is to bring all the three vitiated doshas to normalcy and bring good sleep in turn leads to build up good health. It has been proven from research that, only the deepest and most restful sleep, which is helpful person to be enthusiastic and keeps healthy. The level of sleep required to maintain a good state of health, solely depends on the person's mind-body constitution or Prakruti.
$>$ Ayurveda says three different sleeping disorders based on three Doshas which are;

$>$ (a) Vata Vruddhi is often associated with difficulties in falling asleep. It correlates with hyperactivity, hypersensitivity, anxiety, worry. People with such disorder require 6-7 hours of sleep.

$>$ (b) Pitta Vruddhi is often associated with periodic awakening. It's often correlated with emotional stress, anger, sadness. People with such imbalance have fragmented sleeps almost every 90 minutes. Such people require 7-8 hours of sleep.

$>$ (c) Kapha vruddhi causes an asleep associated with waking up un-refreshed or un-enthusiastic. Persons with such disorders, tend to feel sluggish, tired, and completely exhausted regardless of the long night rest. People with such imbalance need 8-9hours of sleep.

Causes Of Nidranasha (Insomnia):-(1) Tarpak Kapha a bheda of Kapha dosha its job is to do tarpan of the brain cells, resulting in a sound night's sleep. When this dosha is vitiated then the brain cells go un-nourished, leading Nidranasha. (2) PranaVayu is a bheda of Vata dosha, it with the help of Vata vaha siras helps to build a sensitive nervous system and this together with an aggravated PranaVayu, causes Nidranasha. It's then linked to depression, anxiety and worrying. (3)Sadhak Pitta is a bheda of Pitta dosha and it resides in heart. It helps to control of our minds emotions, spirituality, decisiveness and desires. Any imbalance in this creates problems in above said mind 
functions which in turn leading to Nidranasha.

\section{Symptoms Of Nidranasha (Insomnia):-}

\section{(1) Vataja Nidranasha- type insomnia} usually means a restless night in which there is much disturbed sleep leading to change bed turning frequently. If associated with Pitta dosha then person can't get sleep at all, that does tossing and turning or wake up between 2 and 4am (the vata time of the morning), and patient gets sleep only when kapha time starts in early morning.

(2) Pittaja Nidranasha:-Pittaja insomnia is when the patient cannot fall sleep until the pitta time of the night (10pm-2am) is over. The Pittaja nidranasha persons are hyper-aroused. They simply cannot 'switch off' enough to go to sleep. Pittajq. nidranasha will be irritable, and may hav disturbing dreams about fighting, man's more irrelevant dreams, if they don't sleep.

(3) Kaphaja Nidranasha: -Kapha dosha is not normally associated with insomnia, but with excessive sleep, unless a kapha condition (e.g. sleep apnea) interferes with normal sleep. Waking up too early in the morning (6am) may be a type of Kaphaja insomnia, as is feeling sluggish and nonenthusiastic and non-energetic after a full night's sleep.

\section{Treatment Of Nidranasha (Insomnia):-}

Treatment of Nidranasha as per Charaka: - Abhyanga, Utsadana, snana, Jangala Mamsarasa, Shaali anna with Dadhi and Ksheera sevana, sneha, madya sevana, Samvahana, Netra-tarpana, shirolepa, mukhalepa and kala swapna. In sutra sthana $5^{\text {th }}$ chapter charaka says $\mathrm{u}$ must and should go for Murdhni Taila for getting good and sound sleep.

As per Dharakalpa of Sahasrayoga they have said the benefits of doing taila dhara in management of Nidranasha. He says after doing Taila dhara person will benefited with Manas and Vag sthairya, increases the sharira bala, brings ruchi in bhojana, increases the Dhruti (Dharana shakti), swara madhuryata, treats Timiradi vikaras, does Poshana of Shukra and Rakta dhatu and gives sound sleep (suswapna).

So here in Nidranasha we can go for Taila dhara with the help of Brahmi and Jatamamsi taila combination. As we know Tila taila is Marutaghnam, Balavardhanam, brings sthiratha in vata dosha and also sharira. Brahmi is good for Yatanadi samsthana(Balya). Also helps in *eating various Manasika vikaras, its dourbalya and Mano-avasada. Jatamamsi having Sheetal guna with vatanadi shamaka, sadnya sthapaka, medhya, hrudbalya and soumanasya janana. Also it's having effect of Poshaka and does uttejana of Mashtishka and improves Raktabhisarana.

\section{DISCUSSION-}

Ayurveda says diseases are of two types viz, Sharirika and Manasika. These two diseases affects one other, as like if person suffers from sharirika disease in turn it affects the Manas and do Doshana of it leading to various psychological problems. As consequence of which the person and other family members of the same will be in trouble.

Charaka in sutrasthana while explaining the effects of Various Murdhni tailas, he says Nidra laabha sukham cha 
syaat Murdhni taila nishevanat. That means among the four viz, Shiroabhyanga, shiro-seka, shiro-pichu and shirobasti one can administer the Shirodhara with the help of Brahmi and Jatamamsi siddha taila for getting desired effect.

Also in chapter of Dharakalpa of Sahasrayoga auther clearly states the benefits of Shirodhara with taila helps in Su-swapna (sound sleep) by taila sechana (Dhara).

\section{CONCLUSION-}

Charaka Acharya clearly states benefits of application of taila over the scalp in the one of the form of Murdhni taila leads to Sukha nidra. Dharakalpa of Sahasrayoga to explained the application of Taila dhara for su-swapna(Sound sleep). By combining it with Brahmi and jatamansi they helps to control over mind treats various manasika ailments, combad anxiety, depression, irritability, chronic pain, helps to reduce Hypertension and anger of the person which affects the sleep of the person. So among four Murdhni tailas we can say Taila-dhara is good option in treating Nidranasha(Insomnia).

\section{References-}

1. Charaka Samhita Vidyotini Teeka by Kashinath Shastri, Choukhamba Sanskrit samsthana, Varanasi, Reprint edition 2007. Su.5/81-83 pg.no.87

2. Charaka Samhita Vidyotini Teeka by Kashinath Shastri, Choukhamba Sanskrit samsthana, Varanasi, Reprint edition 2007 su.21/35-62 pg.no.283-287

3. Dharakalpa of SahasrayogaDr.D.B.Panditrao, Vangmay Anusandhan ekak, Kendriya Ayurved evam siddha anusandhan parishad New Delhi,13/1-5 pg.no.518-19

4. Bhavaprakasha Nighantu by Prof. Krushnachand Chunekar, choukhamba Bharati academy, Reprint 2013 page no 229

5. Bhavaprakasha Nighantu by Prof. Krushnachand Chunekar, choukhamba Bharati academy, Reprint 2013 page no 447

6. Website- wikipedia https://en.wikipedia.org/wiki/Inso mnia

7. Anubhoota 